\title{
ANALISIS FAKTOR-FAKTOR YANG MEMPENGARUHI PENDAPATAN INDUSTRI KECIL DI KOTA PADANGSIDIMPUAN DAN KABUPATEN TAPANULI SELATAN
}

\author{
Ali Hardana \\ IAIN Padangsidimpuan \\ wardanali0@gmail.com
}

\begin{abstract}
Industrialization is a basic tool for national development and regional development, especially for small industrial business activities that are important in order to realize a just and prosperous society. To achieve this, the government made a policy to increase small industry revenues. The main objective of this research is to find out the number of small business loans (X1), the number of small-scale industrial workers (X2), economic growth (X3), and the number of small-scale industries (X4), significantly affecting Small-Scale Industrial Revenues in Padangsidimpuan City (Y1) and South Tapanuli Regency (Y2). In this study the data used is secondary data obtained from the Central Bureau of Statistics of Padangsidimpuan for 15 years starting from 2002-2016. The data were analyzed using multiple linear regression models, namely an analysis to determine each of the independent variables $(\mathrm{X})$ to the bound variable $(\mathrm{Y})$ both silmultanally and partially. Based on the results of the analysis and testing the hypothesis obtained results of $F_{\text {count }}$ of $18,900>F_{\text {table }}=3,48$ for the City of Padangsidimpuan and for the District of South Tapanuli obtained the results of $F_{\text {count }} 3.616>F_{\text {table }}=3,48$ which means simultaneously the four independent variables have a real influence on industrial income small in Padangsidimpuan City and South Tapanuli Regency. Partial testing of the city of Padangsidimpuan obtained tcount for the variable X1 of 7.367>t-table of 2.228 means that the variable $\mathrm{X} 1$ can contribute to the real effect on the dependent variable Y1. Partial testing of South Tapanuli Regency obtained tcount for variable $\mathrm{X} 2$ of $3.160>\mathrm{t}$-table of 2.228 means that variable $\mathrm{X} 2$ can contribute to the real influence on the dependent variable $Y 2$, for variable $\mathrm{X} 4$, $\mathrm{t}$-count of $2.986>\mathrm{t}$-table of 2.228 means that variable $\mathrm{X} 4$ can contribute to the real influence against the dependent variable $Y 2$.

Keywords: Small-Scale Industry Income, Small-scale business credit, Small-scale industrial workforce, Economic growth, and Small-scale industry.
\end{abstract}

\footnotetext{
Abstrak

Industrialisasi merupakan alat pokok pembangunan nasional dan pembangunan daerah terutama kegiatan usaha industri kecil yang penting dalam rangka mewujudkan masyarakat adil dan makmur. Untuk mewujudkan hal tersebut maka pemerintah membuat kebijaksanaan untuk meningkatkan pendapatan industri kecil. Tujuan utama dari penelitian ini adalah untuk mengetahui Jumlah kredit usaha kecil (X1),
} 
Jumlah tenaga kerja industri kecil (X2), Pertumbuhan ekonomi (X3), dan Jumlah industri kecil (X4), berpengaruh nyata terhadap Pendapatan Industri Kecil di Kota Padangsidimpuan (Y1) dan Kabupaten Tapanuli Selatan (Y2). Dalam penelitian ini data yang digunakan adalah data sekunder yang diperoleh dari Badan Pusat Statistik Padangsidimpuan selama 15 tahun mulai dari tahun 2002-2016. Data yang dianalisis menggunakan model regresi linier berganda yaitu suatu analisis untuk mengetahui masing-masing dari variabel bebas $(X)$ terhadap varibel terikat (Y) baik secara silmultan maupun parsial. Berdasarkan hasil analisis dan pengujian hipotesis diperoleh hasil Fhitung sebesar 18,900 $>F_{\text {tabel }}=3,48$ untuk Kota Padangsidimpuan dan untuk Kabupaten Tapanuli Selatan diperoleh hasil Fhitung sebesar 3,616 $>$ Ftabel $=3,48$ yang berarti secara simultan keempat variabel bebas mempunyai penngaruh yang nyata terhadap pendapatan industri kecil di Kota Padangsidimpuan dan Kabupaten Tapanuli Selatan. Pengujian secara parsial kota Padangsidimpuan diperoleh thitung untuk variabel X1 sebesar 7,367>ttabel sebesar 2,228 berarti variabel X1 dapat memberikan konstribusi pengaruh yang nyata terhadap variabel terikat Y1. Pengujian secara parsial Kabupaten Tapanuli Selatan diperoleh thitung untuk variabel X2 sebesar 3,160>ttabel sebesar 2,228 berarti variabel X2 dapat memberikan konstribusi pengaruh yang nyata terhadap variabel terikat Y2, untuk variabel X4 thitung sebesar 2,986 > tabel sebesar 2,228 berarti variabel $\mathrm{X} 4$ dapat memberikan konstribusi pengaruh yang nyata terhadap variabel terikat $\mathrm{Y} 2$.

Kata Kunci: Pendapatan Industri Kecil, Jumlah kredit usaha kecil, Jumlah tenaga kerja industri kecil, Pertumbuhan ekonomi, dan Jumlah industri kecil.

\section{PENDAHULUAN}

Indonesia sebagai salah satu negara yang sedang berkembang dalam mewujudkan tujuan nasional berusaha untuk mempertahankan dan meningkatkan pertumbuhan ekonomi yang diharapkan, tidak terlepas dari peran pembangunan yang dilakukan oleh masing-masing daerah. Perkembangan daerah sebagai bagian dari pembangunan nasional diarahkan untuk mengembangkan daerah masing-masing dan menyerasikan laju pertumbuhan antar daerah. Hal ini dapat dilakukan melalui pembangunan yang serasi dan terpadu antar sektor dalam mencapai tujuan.

Krisis ekonomi yang mendera bangsa kita mulai pertengahan tahun 1997 hingga beberapa tahun terakhir ini yang kemudian berkembang menjadi krisis multidimensional telah memberikan pelajaran kepada kita bahwa kegiatan ekonomi yang terpusat di tangan beberapa kelompok ekonomi tertentu saja, mempunyai resiko keruntuhan yang besar dikala krisis melanda. Hal ini terbukti dengan banyaknya kegiatan usaha skala besar yang harus gulung tikar dengan 
meninggalkan beban pengangguran yang tidak sedikit. Peristiwa ini membuka mata pemerintah Indonesia berkaitan dengan timpangnya struktur usaha (industri) yang terlalu memihak pada industri besar. Di sisi lain, usaha kecil dan menengah (UKM) yang tumbuh ditengah elemen masyarakat secara spontan justru menunjukkan daya tahan yang lebih tinggi dan menjadi penyangga kehidupan jutaan jiwa.

Industrialisasi merupakan alat pokok pembangunan nasional dan pembangunan daerah yang bertujuan mewujudkan masyarakat yang maju dan mandiri serta sejahtera lahir dan batin. Selain berperan strategis untuk mendukung pertumbuhan ekonomi yang cukup tinggi secara berkelanjutan dan meningkatkan produktivitas masyarakat, juga berperan menciptakan lapangan usaha serta memperluas lapangan kerja, meningkatkan serta meratakan dan mengentaskan kemiskinan.

Perkembangan industri kecil dari waktu ke waktu secara rutin harus dilakukan pengkajian, penyempurna dan peningkatan. Hal ini disebabkan kondisi industri kecil pada umumnya lemah dalam kredit modal kerja. Dalam pembinaan dan pemanfaatan modal akan membawa dampak yang lebih baik terhadap perkembangan pendapatan industri kecil itu sendiri, karena secara langsung kredit merupakan salah satu yang paling penting sebagai faktor penunjang dan pendukung terhadap aktivitas pengusaha dalam meningkatkan pendapatan industri kecil dan memperluas usaha yang dimilikinya. Oleh sebab itu pihak bank memberikan kemudahan dan syarat-syarat yang ringan yaitu tingkat suku bunga yang rendah dan jangka waktu pengambilan yang relatif panjang. ${ }^{1}$

Perkembangan industri kecil dipengaruhi oleh variabel atau faktor yang bersumber dari dalam unit usaha maupun yang berasal dari luar. Faktor dari dalam termaksud antara lain: (1) Kemampuan manajerial, (2) Pengalaman pemilik atau pengelola, (3) Kemampuan untuk mengakses pasar input dan output, teknologi produksi, dan sumber-sumber permodalan, serta (4) Besar kecilnya modal yang dimiliki. Sedangkan beberapa faktor eksternal termaksud, antara lain : (1) Dukungan berupa bantuan teknis dan keuangan dari pihak pemerintah atau swasta, (2) Kondisi perekonomian yang dicerminkan dari 
132 | TAZKIR: Jurnal Penelitian Ilmu-ilmu Sosial dan Keislaman

Vol. 04 No. 1 Juni 2018

permintaan pasar domestik maupun dunia, dan (3) Kemajuan teknologi dalam produksi. $^{2}$

Mengatasi masalah pengangguran di Sumatera Utara tampaknya industri kecil mampu memberikan lapangan kerja baru kepada masyarakat, karena industri kecil bersifat karya sehingga dapat menyerap tenaga kerja dalam jumlah yang sangat besar sehingga dapat mengurangi pengangguran dan kemiskinan. Dalam usaha mendorong kelancaran kegiatan usaha industri kecil di Sumatera Utara tidak terlepas dari berbagai pembinaan dan kebijaksanaan yang dilakukan oleh pemerintah, terutama pemerintah Kota Padangsidimpuan dan Kabupaten Tapanuli Selatan.

Usaha mengembangkan industri kecil perlu adanya peningkatan investasi yang selanjutnya akan berdampak pada peningkatan produksi, maka perlu adanya tambahan tenaga kerja yang ikut menangani terhadap proses produksi. Akibat penambahan tenaga kerja berarti memperbesar pengeluaran upah untuk tenaga kerja tersebut. Sejalan dengan hal tersebut, Kota Padangsidimpuan mengalami penurunan perkembangan industri pada tahun 2014 sebesar Rp. 26,28 milyar. Perkembangan terbesar terjadi pada tahun 2010 sebesar Rp.120,34 milyar ${ }^{3}$.

Proses pengembangannya sektor industri kecil ini memerlukan pembangunan diberbagai sektor untuk mendorong memperbaiki kualitas produk industri kecil di sekitar guna meningkatkan pendapatan industri kecil tersebut. Sedangkan peningkatan pendapatan industri kecil di kabupaten Tapanuli Selatan setiap tahun mengalami kenaikan, Perkembangan terbesar terjadi pada tahun 2011 sebesar Rp. 200,89 milyar. Sedangkan penurunan terbesar terjadi pada tahun 2014 sebesar Rp. 102,2. Hal ini menunjukkan bahwa pendapatan industri kecil di kabupaten Tapanuli Selatan mempunyai potensi yang cukup besar untuk terus ditingkatkan ${ }^{4}$.

Pengembangan sektor industri kecil di kota Padangsidimpuan dan kabupaten Tapanuli Selatan diharapkan pula bisa meningkatkan pendapatan industri kecil itu sendiri serta bisa memperluas lapangan pekerjaan dan kesempatan kerja sehingga dapat menambah pendapatan khususnya masyarakat kecil. Bila sektor ini tumbuh dan berkembang serta diiringi dengan pembinaan

2Suroso, Manajemen Industri Kecil dan Menengah, (Jakarta: PT. Salemba, 2007), hlm. 2 ${ }^{3}$ BPS Tapanuli Selatan ${ }^{4}$ BPS Tapanuli Selatan 
yang baik maka usahanya akan menjadi mantap, sehat, dan dinamis. Tentu saja hal ini tidak lepas dari dorongan usaha dan bantuan dari Pemerintah daerah kota Padangsidimpuan dan kabupaten Tapanuli Selatan melalui dinas perindustrian dan perdagangan masing-masing daerah.

Berdasarkan latar belakang tersebut di atas, maka peneliti tertarik untuk mengamati masalah pendapatan industri kecil di Kota Padangsidimpuan dan Kabupaten Tapanuli Selatan dan mengkaji lebih dalam lagi tentang "FaktorFaktor Yang Mempengaruhi Pendapatan Industri Kecil Di Kota Padangsidimpuan Dan Kabupaten Tapanuli Selatan".

Adapun tujuan penelitian ini adalah sebagai berikut :

1. Untuk mengetahui apakah variabel Jumlah kredit usaha kecil, jumlah tenaga kerja industri kecil, pertumbuhan ekonomi, dan jumlah industri kecil berpengaruh nyata terhadap pendapatan industri kecil di Kota Padangsidimpuan dan Kabupaten Tapanuli Selatan.

2. Untuk mengetahui diantara keempat variabel bebas tersebut yaitu Jumlah kredit usaha kecil, jumlah tenaga kerja industri kecil, pertumbuhan ekonomi, dan jumlah industri kecil manakah yang mempunyai pengaruh paling dominan terhadap variabel terikat yaitu pendapatan industri kecil di Kota Padangsidimpuan dan Kabupaten Tapanuli Selatan.

\section{METODE PENELITIAN}

Penelitian ini dilaksanakan di Kota Padangsidimpuan dan Kabupaten Tapanuli Selatan. Adapun tempat penelitian ini didasarkan atas pertimbangan bahwa masalah dengan upaya meningkatkan pendapatan industri kecil menengah di Kota Padangsidimpuan dan Kabupaten Tapanuli Selatan. Alasan lain adalah bahwa lokasi tersebut merupakan tempat tinggal penulis, sehingga penulis merasa terpanggil dan memiliki keinginan yang kuat untuk meneliti disana. Pelaksanaan penelitian ini dilakukan selama tiga bulan, yaitu bulan Agustus sampai dengan Oktober 2011. Waktu yang ditetapkan ini dipergunakan dalam rangka pengambilan data sampai kepada pengolahan data dan pembuatan laporan hasil penelitian. Data yang dipergunakan dalam penelitian ini adalah data time series (runtut waktu) yang merupakan data sekunder. Data pendapatan industri kecil berbentuk tahunan dari Tahun 2006 - 2016. Data yang 
134 | TAZKIR: Jurnal Penelitian Ilmu-ilmu Sosial dan Keislaman

Vol. 04 No. 1 Juni 2018

telah diperoleh dianalisis untuk mengetahui hasil suatu penelitian. Adapun alat analisis data yang digunakan dalam penulisan penelitian ini adalah:

a) Analisis Kualitatif

Analisis kualitatif yaitu menganalisis data yang berbentuk kata, kalimat, skema dan gambar. ${ }^{5}$ Menganalisis dengan cara memilih data, mengelompokkan data, memberikan gambaran dan menggunakan teori untuk kemudian ditarik kesimpulan.

b) Analisis Kuantitatif

Analisis Kuantitatif yaitu model analisis data berdasarkan atas hasil statistik. Penelitian ini menghubungkan model analisis linier berganda dimana untuk mengetahui besarnya pengaruh variabel bebas terhadap variabel terikat. Adapun perumusan model analisis regresi linier berganda adalah :

$$
Y=\beta_{0}+\beta_{1} X_{1}+\beta_{2} X_{2}+\beta_{3} X_{3}+\beta_{4} X_{4}+E
$$

Dimana :

$\mathrm{Y}=$ Variabel dependent (terikat)

$\beta_{0}=$ Bilangan konstanta

$\beta_{1}=$ Koefisien regresi dari variabel $\mathrm{X} 1$

$\beta_{2}=$ Koefisien regresi dari variabel $\mathrm{X} 2$

$\beta_{3}=$ Koefisien regresi dari variabel $\mathrm{X} 3$

$\beta_{4}=$ Koefisien regresi dari variabel $X 4$

$\mathrm{X}_{1}-\mathrm{X}_{4}=$ Variabel independent (bebas)

$\mathrm{E}=$ Faktor kesalahan, berdasarkan distribusi normal dengan rata-rata 0 , tujuan perhitungan

E diasumsikan 0 .

Kemudian melalui pengembangan model digunakan analisis regresi yang digunakan pada sejumlah penelitian-penelitian yang menggunakan sejumlah model penelitian mengenai sejumlah faktor yang turut mempengaruhi Pendapatan Industri Kecil (PIK) berdasarkan rumusan sebagai berikut (Basuki dan Sulistio, 1997) :

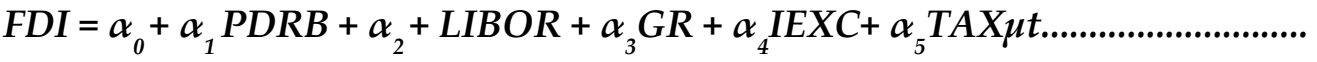
Dimana: $\left(\alpha_{1}>0, \alpha_{2}>0, \alpha_{3}>0, \alpha_{4}>0, \alpha_{5}>0\right)$ 
Berdasarkan variabel-variabel yang digunakan dalam penelitian ini, maka diturunkan sebuah model penelitian mengenai pendapatan investasi modal asing, yaitu :

$Y_{1}=\beta_{0}+\beta_{1}$ GrJKUK $+\beta_{2} J T K I K+\beta_{3} P E+\beta_{4} J I K+U$

$Y_{2}=\beta_{0}+\beta_{1}$ GrJKUK $+\beta_{2} J T K I K+\beta_{3} P E+\beta_{4} J I K+U$

Dimana:

$\mathrm{Y}_{1}=$ Nilai pendapatan industri kecil di kota Padangsidimpuan

$\mathrm{Y}_{2}=$ Nilai pendapatan industri kecil di Kabupaten Tapanuli Selatan

GrJKUK = Jumlah kredit usaha kecil

JTKIK = Jumlah tenaga kerja industri kecil

$\mathrm{PE}=$ Pertumbuhan ekonomi

$\mathrm{JIK}=$ Jumlah industri kecil

$\mathrm{U}=$ Variabel pengganggu

Perhitungan analisis dilakukan dengan menggunakan alat hitung Eviews

9 yang dapat digunakan sebagai dasar menganalisa guna membuktikan hipotesis.

1. Statistik Deskriptif

Statistik deskriptif adalah metode statistik yang berusaha menjelaskan atau menggambarkan berbagai karakteristik data, ${ }^{6}$ seperti berapa rataratanya, seberapa jauh data-data bervariasi, nilai maksimum dan minimum data.

2. Uji Normalitas

Uji normalitas untuk mengetahui normal tidaknya distribusi factor gangguan (residual). Ada dua cara untuk mendeteksi apakah residual berdistribusi normal atau tidak yaitu dengan analisis grafik dan uji statistik. Analisis grafik adalah dengan grafik histogram dan melihat normal probability plot yaitu dengan membandingkan distribusi kumulatif dengan distribusi normal. Sedangkan uji statistik dilakukan dengan melihat nilai kurtosis dan skewness dari residual.

3. Asumsi Klasik

a. Uji Multikolonieritas

Multikolonieritas dapat dideteksi pada model regresi apabila pada variabel terdapat pasangan variabel terdapat pasangan variabel bebas hlm. 200

${ }^{6}$ Muhammad, Firdaus, Metodologi Penelitian Ekonomi Islam (Jakarta: Rajawali Pers, 2008), 
136 | TAZKIR: Jurnal Penelitian Ilmu-ilmu Sosial dan Keislaman

Vol. 04 No. 1 Juni 2018

yang saling berkolerasi kuat satu sama lain. Apabila pada regresi terdeteksi adanya kasus multikolonieritas, maka terjadi perubahan koifisien regresi dari positif pada saat diuji dengan regresi sederhana, menjadi negatif pada saati diuji dengan regresi berganda, atau sebaliknya. Suatu regresi dikatakan terdeteksi multikolonieritas apabila nilai VIF menjauhi 1 atau tolerance menjauhi 1 pada outputcoefficient. ${ }^{7}$

b. Uji Heteroskedastisitas

Heteroskedastisitas asadalah varian residual yang tidak konstan pada regresi sehingga akurasi hasil prediksi menjadi meragukan. Heteroskedastisitas dapat diartikan sebagai ketidaksamaan variasi variabel pada semua pengamatan, dan kesalahan yang terjadi memperlihatkan hubungan yang sistematis sesuai dengan besarnya satu atau lebih variabel bebas sehingga kesalahan tersebut tidak random (acak). Suatu regresi dikatakan terdeteksi heteroskedastisitas-nya apabila diagram pencar residual membentuk pola tertentu. ${ }^{8}$

4. Uji Hipotesis

a. Uji Parsial dengan T-Test

Uji parsial dengan t-test pada dasarnya menunjukkan seberapa jauh pengaruh satu variabel penjelas secara individual dalam menerangkan variasi variabel terikat. ${ }^{9}$ Pengujian hipotesis koefisien regresi secara parsial dilakukan dengan cara membandingkan nilai $\mathrm{t}$ hitung dengan $\mathrm{t}$ tabel yaitu: ${ }^{10}$

1) Jika $\mathrm{T}$ hitung $<-\mathrm{T}$ tabel atau $\mathrm{T}$ hitung $>+\mathrm{T}$ tabel maka $\mathrm{H}_{0}$ ditolak dan $\mathrm{H}_{\mathrm{a}}$ diterima.

2) Jika $-\mathrm{T}$ tabel $\leq \mathrm{T}$ hitung $\leq \mathrm{T}$ tabel maka $\mathrm{H}_{0}$ diterima dan $\mathrm{H}_{a}$ ditolak. Dengan kata lain, jika $\mid \mathrm{T}$ hitung $\mid>\mathrm{T}$ tabel maka $\mathrm{H}_{0}$ ditolak dan $\mathrm{H}_{\mathrm{a}}$ diterima.

7Triton Prawira Budi, SPSS 13.0 Terapan: Riset Statistik Parametrik (Yogyakarta: CV. Andi Offse, 2006), hlm.156

8Triton Prawira Budi, SPSS 13.0 Terapan: Riset Statistik...., hlm. 154

${ }^{9}$ Triton Prawira Budi, SPSS 13.0 Terapan: Riset Statistik...., hlm. 238

${ }^{10}$ Muhammad, Firdaus, Metodologi Penelitian...., hlm. 147 
b. Uji Simultan dengan F-Test

Uji simultan dengan F-test pada dasarnya menunjukkan apakah semua variabel bebas yang dimasukkan dalam model mempunyai pengaruh secara bersama-sama terhadap variabel terikat. ${ }^{11}$ Keputusan atas penerimaan hipotesis pada uji simultan berdasarkan nilai $\mathrm{F}$ hitung adalah sebagai berikut: ${ }^{12}$

1) Jika $\mathrm{F}$ hitung $>\mathrm{F}$ tabel, maka $\mathrm{H}_{0}$ ditolak dan $\mathrm{H}_{\mathrm{a}}$ diterima.

2) Jika $\mathrm{F}$ hitung $<\mathrm{F}$ tabel, maka $\mathrm{H}_{0}$ diterima dan $\mathrm{H}_{\mathrm{a}}$ ditolak.

Selain itu pengujian hipotesis dapat didasarkan pada dua hal, yaitu tingkat signifikansi atau probabilitas $(\alpha)$ dan tingkat kepercayaan atau confidence interval. Berdasarkan tingkat signifikansi, pada umumnya orang menggunakan 0,05 dengan tingkat signifikansi mulai dari 0,01 sampai $0,1 .^{13}$

5. Uji koefisien determinasi $\mathrm{R}^{2}$

Koefisien determinasi $\left(\mathrm{R}^{2}\right)$ pada intinya mengukur seberapa jauh kemampuan model dalam menerangkan variasi variabel terikat. Formula menghitung koefisien determinasi adalah:

$\mathrm{R}^{2}$ $=($ TSS-SEE $) /$ TSS $=$ SSR $/$ TSS

Dimana:

$\mathrm{R}^{2} \quad$ = koefisien determinasi

TSS = total sum of squares (total jumlah kuadrat)

SSE $\quad=$ sum of squares error (variasi kesalahan)

SSR sum of squares due to regression (variasi regresi)

Persamaan tersebut menunjukkan proporsi TSS yang diterangkan oleh variabel independen dalam model. Sisanya dijelaskan oleh variabel lain yang tidak dimasukkan dalam model. Nilai koefisien determinasi adalah di antara 0 (nol) dan 1 (satu). Nilai koefisien determinasi yang kecil berarti kemampuan variabel-variabel independen dalam menjelaskan variabelvariabel dependen amat terbatas. Nilai yang mendekati 1 (satu) berarti

${ }^{11}$ Mudrajat Kuncoro, Metode Riset Untuk Bisnis dan Ekonomi (Jakarta: Erlangga, 2009), hlm. 
variabel-variabel independen memberikan hampir semua informasi yang dibutuhkan untuk memprediksi variasi variabel dependen.

Secara umum koefisien determinasi untuk data runtut waktu biasanya mempunyai nilai koefisien determinasi yang tinggi. Setiap penambahan satu variabel independen maka $\mathrm{R}^{2}$ pasti meningkat. Oleh karena itu, banyak peneliti menganjurkan untuk menggunakan nilai adjusted $\mathrm{R}^{2}$ pada saat mengevaluasi mana model yang terbaik. adjusted $\mathrm{R}^{2}$ dihitung dari:

$$
\text { Adjusted } \mathrm{R}^{2}=1-(\mathrm{n}-1)\left[\frac{\mathrm{s}^{2}}{\mathrm{TSS}}\right]=1-\left(1-R^{2}\right)\left[\frac{\mathrm{n}-1}{\mathrm{n}-\mathrm{k}}\right]
$$

Tidak seperti $\mathrm{R}^{2}$, nilai adjusted $\mathrm{R}^{2}$ dapat naik atau turun apabila satu variabel independen ditambahkan ke dalam model. ${ }^{14}$

6. Analisis Regresi Berganda

Menurut Iskandar regresi berganda adalah teknik untuk menentukan korelasi antara dua atau lebih variabel bebas dengan variabel terikat. ${ }^{15}$ Dalam penelitian ini analisis regresi berganda digunakan untuk menguji pengaruh antara Jumlah kredit usaha kecil, jumlah tenaga kerja industri kecil, pertumbuhan ekonomi, dan jumlah industri kecil terhadap pendapatan industri kecil. Dihitung dengan menggunakan persamaan garis regresi berganda berikut:

$$
\mathrm{PIK}=\mathrm{a}+\mathrm{B}_{1} \mathrm{JKUK}+\mathrm{B}_{2} \mathrm{JTKIK}+\mathrm{B}_{3} \mathrm{PE}+\mathrm{B} \mathrm{JIK}+\mathrm{e}
$$

Keterangan:

PIK = Pendapatan industri kecil (Y)

a $\quad=$ konstanta

$\mathrm{b} \quad=$ koefisien korelasi

JKUK = Jumlah kredit usaha kecil $\left(\mathrm{X}_{1}\right)$

JTKIK = Jumlah tenaga kerja industri kecil $\left(\mathrm{X}_{2}\right)$

$\mathrm{PE} \quad=$ Pertumbuhan ekonomi $\left(\mathrm{X}_{3}\right)$

JIK = Jumlah industri kecil $\left(X_{4}\right)$ 


\section{HASIL PENELITIAN DAN PEMBAHASAN}

\section{Uji Normalitas}

Uji normalitas dengan mempergunakan JB Test dihasilkan sebagaimana ditunjukkan dalam grafik. JB Test 4,154803 dengan probabilitas sebesar 0,125255 yang lebih dari 0,05 maka hal ini menunjukkan bahwa nilai JB hitung dengan probabiltas sebesar 0,125255 yang lebih besar dari 0,05 maka yang menyatakan bahwa residual $\mu_{1}$ berdistribusi normal tidak dapat ditolak. Hasil eviews ditunjukkan dalam grafik berikut di bawah ini :

\section{Grafik 1}

Uji Normalitas

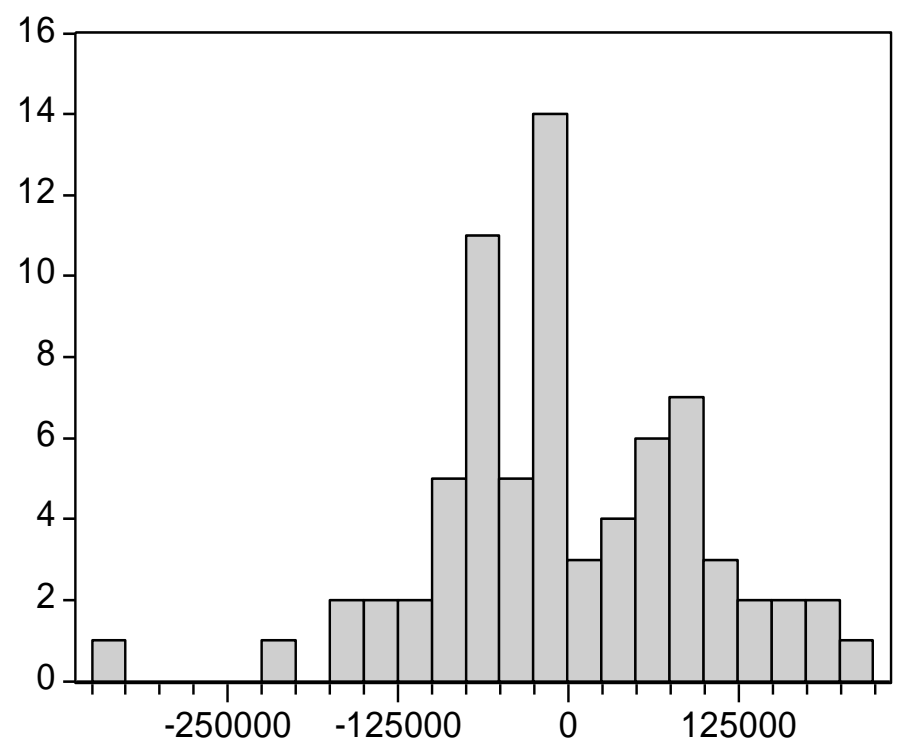

Series: Residuals

Sample 173

Observations 73

Mean

$-2.39 \mathrm{E}-12$

Median

$-11591.20$

Maximum $\quad 212031.1$

Minimum $\quad-344640.3$

Std. Dev. $\quad 98326.89$

Skewness $\quad-0.318603$

Kurtosis $\quad 3.979761$

Jarque-Bera 4.154803

Probability $\quad 0.125255$

\section{Uji Multikolineritas}

Berikut disajikan table data untuk uji multikolineritas.

Tabel 1

Uji Multikolineritas

\begin{tabular}{ccccc}
\hline Variabel & $\begin{array}{c}\text { Jumlah kredit } \\
\text { usaha kecil }\end{array}$ & $\begin{array}{c}\text { Jumlah tenaga } \\
\text { kerja industry } \\
\text { kecil }\end{array}$ & $\begin{array}{c}\text { Pertumbuhan } \\
\text { ekonomi }\end{array}$ & $\begin{array}{c}\text { Jumlah } \\
\text { industry } \\
\text { kecil }\end{array}$ \\
\hline $\begin{array}{c}\text { Jumlah kredit usaha } \\
\text { kecil }\end{array}$ & 1,000000 & 0,279374 & 0,000107 & 0,316106 \\
$\begin{array}{c}\text { Jumlah tenaga kerja } \\
\text { industry kecil }\end{array}$ & 0,279374 & 1.000000 & 0,021922 & 0,298257 \\
$\begin{array}{c}\text { Pertumbuhan ekonomi } \\
\text { Jumlah industri kecil }\end{array}$ & 0,000107 & 0,021922 & 1.000000 & 0,000653 \\
\hline
\end{tabular}

Sumber : Hasil regresi, diolah eviews 2018 
140 | TAZKIR: Jurnal Penelitian Ilmu-ilmu Sosial dan Keislaman

Vol. 04 No. 1 Juni 2018

\section{Uji Heteroskedastisitas}

Salah satu asumsi penting dalam analisa regresi adalah variasi gangguan acak $(\mu)$ pada setiap variabel bebas adalah homoskedastisitas. Ketidaksamaan inilah yang disebut sebagai heteroskedastisitas. Untuk mendeteksi ada tidaknya masalah ini digunakan model uji White Heteroskedasticity Test, dimana dari hasil menunjukkan bahwa hasil dari tabel tersebut ditunjukkan bahwa Obs* $R$-Squared 55,98430 dengan probability 0,000001 yang lebih kecil dari 0,05 menunjukkan bahwa model terjadi heteroscedasticity, namun hal tersebut tidak dapat dihindari. Lebih lengkap ditunjukkan dalam tabel 4.9 berikut di bawah ini.

\section{Tabel 2}

Uji Heteroskedastisitas

White Heteroskedasticity Test:

\begin{tabular}{llll}
\hline \hline F-statistic & 3.550535 & Probability & 0.004158 \\
Obs*R-squared & 17.81303 & Probability & 0.006717 \\
\hline \hline
\end{tabular}

Test Equation:

Dependent Variable: RESID ${ }^{\wedge} 2$

Method: Least Squares

Date: 07/26/18 Time: 03:32

Sample: 173

Included observations: 73

\begin{tabular}{crrrr}
\hline \hline Variable & Coefficien & Std. Error & t-Statistic & Prob. \\
& $\mathrm{t}$ & & & \\
\hline \hline C & $6.83 \mathrm{E}+11$ & $8.05 \mathrm{E}+11$ & 0.847684 & 0.3997 \\
JKUK & $-8.24 \mathrm{E}+10$ & $5.24 \mathrm{E}+11$ & -0.157322 & 0.8755 \\
JKUK^2 & $1.35 \mathrm{E}+10$ & $8.72 \mathrm{E}+10$ & 0.155365 & 0.8770 \\
JTKIK & $-6.38 \mathrm{E}+11$ & $3.36 \mathrm{E}+11$ & -1.896667 & 0.0622 \\
JTKIK^2 & $1.32 \mathrm{E}+11$ & $4.95 \mathrm{E}+10$ & 2.673650 & 0.0094 \\
JIK & 2396838. & 2660893. & 0.900764 & 0.3710 \\
JIK^2 & -3.072469 & 2.423228 & -1.267924 & 0.2093 \\
\hline \hline R-squared & 0.244014 & \multicolumn{2}{l}{ Mean dependent var } & $4.42 \mathrm{E}+11$ \\
Adjusted R-squared & 0.175288 & \multicolumn{2}{l}{ S.D. dependent var } & $1.13 \mathrm{E}+12$ \\
S.E. of regression & $1.03 \mathrm{E}+12$ & \multicolumn{2}{l}{ Akaike info criterion } & 58.24711
\end{tabular}


Sum squared resid

6.98E+25 Schwarz criterion

58.46674

Log likelihood

-2119.020 F-statistic

3.550535

Durbin-Watson stat

2.083835 Prob(F-statistic)

0.004158

\section{Uji Statistik}

Hasil uji statistic dapat dilihat dalam table di bawah ini:

Tabel 3

Hasil Estimasi

Dependent Variable: PIK

Method: Least Squares

Date: 07/26/18 Time: 03:23

Sample: 173

Included observations: 73

\begin{tabular}{crlll}
\hline \hline Variable & $\begin{array}{rlll}\text { Coefficien } \\
\mathrm{t}\end{array}$ & Std. Error & t-Statistic & Prob. \\
\hline \hline C & 130972.4 & 295647.4 & 0.443002 & 0.6591 \\
JKUK & -270691.6 & 109935.5 & -2.462276 & 0.0163 \\
JTKIK & 158717.2 & 51741.42 & 3.067507 & 0.0031 \\
JIK & 4.501177 & 0.547220 & 8.225540 & 0.0000 \\
\hline \hline R-squared & 0.717188 & Mean dependent var & 897123.3 \\
Adjusted R-squared & 0.704892 & S.D. dependent var & 1256322. \\
S.E. of regression & 682482.3 & Akaike info criterion & 29.75810 \\
Sum squared resid & $3.21 \mathrm{E}+13$ & Schwarz criterion & 29.88360 \\
Log likelihood & -1082.171 & F-statistic & 58.32618 \\
Durbin-Watson stat & 1.867353 & Prob(F-statistic) & 0.000000 \\
\hline \hline
\end{tabular}

Sumber : Olahan Eview, 2018

\section{Uji R}

Besarnya nilai koefisien determinasi $\left(\mathrm{R}^{2}\right)$ digunakan untuk mengetahui berapa besar proporsi sumbangan variabel bebas secara bersama-sama terhadap variabel tak bebasnya. Berdasarkan hasil estimasi pada tabel 3 di atas, diperoleh nilai koefisien determinasi $\left(\mathrm{R}^{2}\right)$ sebesar 0,717188 yang berarti variasi variabel bebas (jumlah kredit usaha kecil, jumlah tenaga kerja industri kecil dan jumlah industri kecil) di Kota Padangsidimpuan dan Kabupaten Tapanuli Selatan 
142 | TAZKIR: Jurnal Penelitian Ilmu-ilmu Sosial dan Keislaman

Vol. 04 No. 1 Juni 2018

sebesar 72 persen dan sisanya 28 persen dijelaskan oleh variabel lain yang tidak terdapat dalam model estimasi tersebut.

\section{Uji F}

Berdasarkan hasil pengujian diperoleh bahwa nilai F-test dimunculkan oleh hasil pengolahan data. Hal ini terjadi karena model dikembangkan tanpa nilai konstanta. Namun jika model tersebut dikembangan dengan memunculkan nilai konstanta di F test diperoleh dengan F-test adalah 58,32618 dan dengan probability sebesar 0,00000 . Nilai $P$-Value berarti secara bersama-sama variabel mempunyai pengaruh signifikan dan positif terhadap pendapatan industri kecil di Kota Padangsidimpuan dan Kabupaten Tapanuli Selatan pada tingkat kepercayaan $100 \%$.

\section{Uji $\mathbf{t}$}

Uji t digunakan untuk menguji pengaruh secara parsial dari setiap variabel yang diamati. Uji parsial adalah uji kebermaknaan setiap variabel bebas terhadap variabel terikat. Uji statistik secara parsial dapat dijelaskan sebagai berikut :

a) Jumlah kredit usaha kecil mempunyai arah positif dan signifikan pada tingkat kepercayaan 95\% terhadap pendapatan industri kecil di Kota Padangsidimpuan, dimana $t$-ratio sebesar 8,531661 atau probability 0,0000 .

b) Variabel jumlah tenaga kerja industri kecil mempunyai pengaruh positif dan signifikan terhadap peningkatan pendapatan industri kecil, karena dimana $t$ ratio sebesar 2,063014 atau probability 0,0429 bersignifikan pada tingkat kepercayaan $95 \%$.

c) Variabel pertumbuhan ekonomi mempunyai pengaruh positif dan signifikan terhadap peningkatan pendapatan industri kecil, karena dimana t-ratio sebesar 7,813728 atau probability 0,00000 bersignifikan pada tingkat kepercayaan $95 \%$.

d) Variabel jumlah industri kecil mempunyai pengaruh positif dan signifikan terhadap peningkatan pendapatan industri kecil, karena dimana t-ratio sebesar 2,431306 atau probability 0.0177 bersignifikan pada tingkat kepercayaan 95\%. 


\section{Uji Apriori Ekonomi}

Berdasarkan hasil perhitungan regresi yang terdapat pada tabel 3 di atas dapat diketahui persamaan regresi yang diperoleh adalah sebagai berikut: PIK $=$ - 413588,3+102771,6JKUK+19723,45JTKIK+43,19638PE+0,096646 JIK

t hitung $\quad(8,532)$
$\mathrm{R}^{2} \quad=0,860$
F ratio $=104,586$

Berdasarkan hasil analisis regresi di atas, dapat diketahui bahwa faktorfaktor pendapatan industri kecil di Kota Padangsidimpuan dan Kabupaten Tapanuli Selatan seperti Jumlah kredit usaha kecil, jumlah tenaga kerja industri kecil, pertumbuhan ekonomi, dan jumlah industri kecil ternyata dapat disimpulkan signifikan dalam mempengaruhi hasil pendapatan industri kecil. Hal ini dapat dibuktikan bahwa dari hasil pengolahan data hasil estimasi tabel 4.10 yang merupakan output dari pengolahan model regresi, dapat disimpulkan sebagai berikut :

1. Pengaruh Jumlah Kredit Usaha Kecil Terhadap Hasil Pendapatan Industri Kecil

Berdasarkan analisis data parsial di atas, diketahui jumlah kredit usaha kecil signifikan mempengaruhi pendapatan industri kecil. Dengan koefisien regresi sebesar 102771,6 dapat diartikan setiap pertambahan jumlah kredit usaha kecil sebesar Rp. 1 maka akan meningkatkan pendapatan industri kecil sebesar Rp. 102.772. Berdasarkan hasil estimasi ini menunjukkan bahwa faktor jumlah industri kecil secara parsial berpengaruh signifikan terhadap hasil pendapatan industri kecil.

2. Pengaruh Jumlah Tenaga Kerja Industri Kecil Terhadap Hasil Pendapatan Industri Kecil

Berdasarkan hasil uji estimasi di atas, dapat disimpulkan bahwa variabel jumlah tenaga kerja industri kecil secara parsial berpengaruh secara signifikan terhadap hasil pendapatan industri kecil. Dalam hal ini koefisien input produksi salak pada faktor jumlah tenaga kerja industri kecil sebesar 19723,45. Ini dapat diartikan, jika variabel jumlah tenaga kerja industri kecil bertambah satu orang, maka dapat diperkirakan jumlah produksi salak yang akan dihasilkan akan meningkat sebesar 19423 orang. Dengan kata lain dapat diinterpretasikan bahwa penambahan jumlah tenaga kerja industri kecil akan meningkatkan hasil 
144 | TAZKIR: Jurnal Penelitian Ilmu-ilmu Sosial dan Keislaman

Vol. 04 No. 1 Juni 2018

pendapatan industri kecil pada usaha industri kecil menengah di Kota Padangsidimpuan dan Kabupaten Tapanuli Selatan.

3. Pengaruh Variabel Jumlah Industri Kecil Terhadap Hasil Pendapatan Industri Kecil

Berdasarkan hasil uji estimasi ini dapat disimpulkan, bahwa variabel jumlah industri kecil secara parsial berpengaruh secara signifikan terhadap hasil pendapatan industri kecil. Dengan koefisien regresi sebesar 43,19638 dapat diartikan setiap kenaikan jumlah industri kecil sebesar 1 unit maka akan menaikkan pendapatan industri kecil di Kota Padangsidimpuan dan Kabupaten Tapanuli Selatan sebesar 43,2 unit.

4. Pengaruh Variabel Pertumbuhan Ekonomi Terhadap Hasil Pendapatan Industri Kecil

Berdasarkan hasil uji statistik di atas dapat disimpulkan, bahwa variabel pertumbuhan ekonomi secara parsial berpengaruh secara signifikan terhadap hasil pendapatan industri kecil. Dengan koefisien regresi sebesar 0,096646 dapat diartikan setiap kenaikan pertumbuhan ekonomi sebesar Rp. 1,- maka akan meningkatkan pendapatan industri kecil sebesar Rp. 0,09.

Berdasarkan hasil analisis statistik pada tabel 4.10 hasil estimasi (lampiran 1) maka, uji parsial pada fungsi regresi estimasi PIK = $\mathrm{f}$ (JKUK, JTKIK, $\mathrm{PE}, \mathrm{JIK})$ bertujuan untuk membuat kesimpulan mengenai pengaruh masingmasing variabel independen terhadap variabel dependen. Pengujian koefisien regresi dengan mengunakan nilai probabilitas ( $p$-value) dengan tingkat signifikansi (alpha) yang digunakan. Jika nilai probabilitas ( $\mathrm{p}$-value) lebih kecil dari pada tingkat signifikansi (alpha) yang digunakan, keputusannya adalah menolak hipotesis nol $\left(\mathrm{H}_{0}\right)$ dan menerima hipotesis alternatif (Ha). Artinya variabel independen yang diuji berpengaruh secara signifikan (bermakna) terhadap variabel dependen. Sebaliknya, jika probabilitas menerima hipotesis non probability lebih besar dari tingkat signifikansi (alpha) yang digunakan. 


\section{DAFTAR PUSTAKA}

BN, Marbun, Kamus Manajemen, Jakarta: Pustaka Sinar Harapan, 2003.

Departemen Agama, Alqur'an dan Terjemahan, Surabaya: PT. Thoha Putra, 1999.

Departemen Pendidikan dan Kebudayaan, Kamus Besar Bahasa Indonesia, Jakarta: Balai Pustaka, 1998.

Iskandar, Metodologi Penelitian Pendidikan dan Sosial (Kuantitatif dan Kualitatif),

Jakarta: Gaung Persada Press, 2010.

Jonathan Sarwono, Metode Penelitian Kuantitatif dan Kualitatif, Yogyakarta: Graha Ilmu, 2006.

Kadariah, Teori Ekonomi Mikro, Jakarta: LPFE UI, 1994.

Mubyarto, Pengantar Ekonomi Pertanian, Jakarta: LP3ES, 1973.

Mudrajat Kuncoro, Metode Riset Untuk Bisnis dan Ekonomi, Jakarta: Erlangga, 2009.

Muhammad, Metodologi Penelitian Ekonomi Islam, Jakarta: Rajawali Pers, 2008.

Reksoprayitno, Sistem Ekonomi dan Demokrasi Ekonomi, Jakarta: Bina Grafika, 2004.

Sugiyono, Metode Penelitian Bisnis, Bandung: Alfabeta, 2002.

Sumitro, Ilmu Ekonomi, Jakarta: Rineka Cipta, 1991.

Triton Prawira Budi, SPSS 13.0 Terapan: Riset Statistik Parametrik, Yogyakarta: CV. Andi Offse, 2006.

Winardi, Kamus Ekonomi Inggris-Indonesia, Bandung: Mandar Maju, 1998. 
146 | TAZKIR: Jurnal Penelitian Ilmu-ilmu Sosial dan Keislaman

Vol. 04 No. 1 Juni 2018

\section{UPAYA ORANGTUA DALAM MEMBIMBING PELAKSANAAN IBADAH SALAT REMAJA PENGGUNA MEDIA SOSIAL DI DESA PARGARUTAN DOLOK ANGKOLA TIMUR}

Desi Indriani, Agus Salim Lubis \& Maslina Daulay

IAIN Padangsidimpuan

agussalimlubis2@gmail.com 